\author{
土’木学会論文報告集 \\ 第 313 号・1981年 9 月 \\ 【論文】

\section{円柱橋脚周辺の静的洗掘に関する研究 \\ STUDY ON THE CLEAR WATER SCOUR AROUND \\ A CYLINDRICAL BRIDGE PIER}

\author{
鈴 木 幸 一* \\ By Koichi SUZUKI
}

\section{1. まえがき}

橋脚周辺の局所洗掘現象は, 流れと河床面形状との相 互作用による複雑な現象であるが，その内部機構を説明 しようとすると，ある境界面形状に対応する局所流とそ の局所流に対応する砂の移動特性および非平衡状態の流 砂量等の問題が明らかにされなければならないが，現在 のところこれらの問題は現象が定常な場合にも不明な点 が多く，まして非定常な流れと河床面の相互作用を微視 的にとらえることは非常に困難である.このため，橋脚 周辺の局所洗掘に関する従来の多くの研究は, おもに水 理模型実験結果を次元解析する方法に頼っている. しか し，実験事実に基づいて，ごく巨視的に洗掘孔における 流砂の連続式を考慮したモデルによって解析するという 研究も数多く, そのおもなものを挙げると表一1のよう である。

局所洗掘現象は上にも述べたように, 流れ, 砂の動き および洗掘孔形状の相互作用であり，それぞれに関する とらえ方が研究者によって異なっている. すなわら, 洗 掘を生ぜしめる流れに関しては, 橋脚側面での縮流に注 目したもの (Laursen ${ }^{1)}$, 斉藤 ${ }^{2}$, $\left(G r a d o w c z y k{ }^{3}\right)$, 単に 上流側の一様流速を代表させるもの $\left(\right.$ Carstens $\left.^{4}\right)$ ), 橋脚 周辺底部に起こる馬蹄型渦に注目するもの (Shen ${ }^{5)}$, Tanaka $^{6)}$, 吉川 ${ }^{7)}$ ) あるいは洗掘孔内での流れの拡散を 考えるもの (Tarapore ${ }^{8)}$ ) などがある.はた，洗掘孔形
状に関しては，実験的事実に基づいて逆円錐形を仮定し ているものがほとんでであり, 砂の動きに関しては, 各 種の従来の平衡状態での流砂量式を修正して用いてい る.これらのモデルに扔いては, 流砂の洗掘孔内への, また洗掘孔からの出入がバランスするところでの洗掘深 を求めることに主眼が置かれているため, 洗掘深の時間 的変化を打もに扱ったものは少なく，また clear water scour (以後, 静的洗掘とよぶ) と scour with continuous sediment motion (以後, 動的洗掘とよぶ) の洗掘特性 の相違を明確にして解析したものも少ない.すなわち， 上述の従来の多くのモデル解析では, 洗掘領域全体を 1 つの流砂量式の適用範囲としているため, 橋脚による流 れの変化, 渦の発生などを考慮した合理的な流砂量式を 与える, などの洗掘の内部機構に基づく解析がなされて いないという久陥がある。

本研究では，橋脚周辺部における静的洗掘の諸特性を 実験的に明らかにするとともに, 実験事実に基づいて, 非平衡な流砂量など洗掘の内部機構を考慮したモデルに よる解析によって, 洗掘深の場所的, 時間的変化特性を 明らかにしょうとするものである.

ここで, 特に, 一様流場では砂の移動はなく橋脚周辺 部でのみ砂の移動がある静的洗掘のみを扱ったのは, 流 勢の強い動的洗掘では上流からの洗掘孔への流入土砂量 が大きくなるため, 最大洗掘深は静的洗掘状態で発生す ることと, 内部機構の解明に関しての複雑性を避けるた めである.

表-1 橋脚周辺の局所洗掘に関するモデル解析

\begin{tabular}{l|l|c|c}
\hline Investigator & \multicolumn{1}{|c|}{ Model for flow } & Scour hole shape & Model for Sediment movement \\
\hline Laursen & Constriction & reverse-cone & Crtitcal tractive force \\
Saito & Constriction & $\begin{array}{c}\text { (front) reverse-cone } \\
\text { (back) trigonal-piramid }\end{array}$ & Kalinske-Brown formura \\
Carstens & $u_{o} / \sqrt{(\sigma / \rho-1) g d}$ & reverse-cone & Experimental formura \\
Shen & Horse shoe Vortex & reverse-cone & Du Boy's formura \\
Tarapore & Velocity diffusion at the scour hole & reverse-cone & Du But \\
\hline
\end{tabular}

* 正会員 工博 鳥取大学助教授 工学部土木工学科 


\section{2. 静的洗掘に関する実験注 1)}

\section{（1）実験装置と実験方法}

実験水路は長さ $14 \mathrm{~m}$, 幅 $98 \mathrm{~cm}$, 深さ $30 \mathrm{~cm}$ の木製 であって，その中央部が一部透明アクリル樹脂でできて おり，この部分のみ水路底より下 $15 \mathrm{~cm}$ の深さの箱部 が設けてあり，ここに円柱橋脚模型を設置し砂が敷ける ようにしてある．使用した 円柱は塩化ビニール製であ り,この円柱の上流端面, 斜め上流側面㧍よび側面の 3 か所にポイントゲージが取り付けてあり，その 3 か所で の洗掘深が測定できるようになっている. 実験条件注 2) は表一2に示すとおりであって, 用いた円柱の直径は， $8.9 \mathrm{~cm}$ および $14.0 \mathrm{~cm}$ の 2 種類で, 一様流の平均流速 v。は $20.80,26.05$ および $37.04 \mathrm{~cm} / \mathrm{s}$ の 3 通り変化さ せた．また，円柱周辺河床砂は図一1に示すような粒径 加積曲線をもつ, 中央粒径が $0.083 \mathrm{~cm}$ および $0.193 \mathrm{~cm}$ の 2 種類である.

実験の方法は，まず水路中央部底箱に円柱を設置し， その底箱に砂を上下流部の水路床と同じ高さまで敷き， 円柱周辺の移動床部を押え板で保護した状態で通水し， 流れが定常になってからこの押え板を流れを乱さないよ らにゆっくり取り除いた後, 洗掘深の時間的変化を測定 する. 洗掘測定は円柱の 3 か所に付置したポイントゲー

表一2 実験条件

\begin{tabular}{c|c|c|c|c}
\hline Run & $D(\mathrm{~cm})$ & $d_{50}(\mathrm{~cm})$ & $h_{o}(\mathrm{~cm})$ & $v_{o}(\mathrm{~cm} / \mathrm{s})$ \\
\hline 1 & 14.0 & 0.193 & 13.62 & 26.05 \\
2 & 14.0 & 0.193 & 9.58 & 37.04 \\
3 & 8.9 & 0.193 & 17.06 & 20.80 \\
4 & 8.9 & 0.193 & 13.62 & 26.05 \\
5 & 8.9 & 0.193 & 9.85 & 37.04 \\
6 & 8.9 & 0.083 & 17.06 & 20.80 \\
7 & 8.9 & 0.083 & 13.62 & 26.05 \\
\hline
\end{tabular}

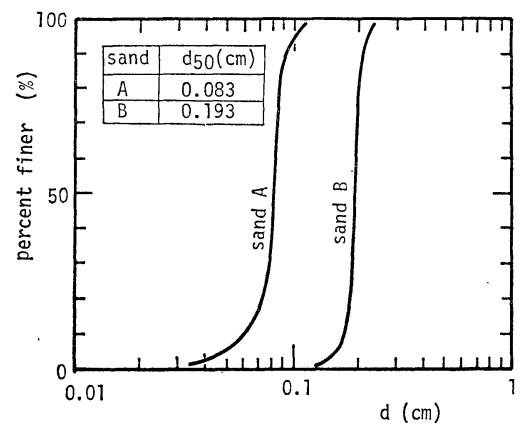

図一1 実験砂の粒径加積曲線

注 1）一部既報9)

注 2) ここでは，既報の実験 25 ケースの中で以下の解析の 検証のために洗掘哚の場所的・時閒的変化を詳細に測定 した 7 ケースについてのみ示す.
ジによって, 円柱橋脚周辺の最大洗掘深について行らが 測定時間間隔は通水後 5 分までは 30 秒, 20 分後までは 1 分間隔, 以後は 5 分間隔, 10 分間隔之適宜洗掘進行 状態によって変化させ, 通水後 4 時間経過まで測定する のを原則とした．また，洗掘孔形状は，測定したい時間 に水路下流端の水位調節用板を引き上げ水位を十分大き くして通水を停止した後徐々に排水し，各場所の標高を ポイントゲージで測定し，白系によって等高線を描いた 後, 写真によって記録した.

\section{(2) 洗掘形状}

図一2 は Run 6 についての円柱周辺部における局所 的な河床形態を示したものであって, 通水後 10 分, 30 分, 1 時間, 8 時間および 13 時間 30 分のものである. 洗掘のごく初期を除いては, 円柱上流側半分での洗掘孔 はほぼ逆円錐形となっている，洗掘孔内で実際に砂が流 れによって洗掘されている領域は円柱にごく近い一部河 床のみで, 洗掘孔内のその他の部分は砂の水中静止摩擦 角（約 $45^{\circ}$ ) の傾きをもつ斜面を形成しているだけで, 洗掘されている領域の河床が低下すると斜面の傾きを砂 の摩擦角に保つように砂が斜面から滑落しているに過ぎ ないことが，実験観察より認められた。洗掘初期には， 円柱上流端に比して, 円柱の斜め上流面河床から側面河 床へかけての洗掘梁がより大きくなっているが，やがて それらの洗掘深注とんど等しくなり, 洗掘孔底部での 洗掘深は円柱周に沿ってほとんど変わらない状態で洗掘 が進行する.さらに洗掘が進むと, 最大洗掘深の位置は 円柱の上流端に移ってゆき，洗掘孔形状は円柱の中心を

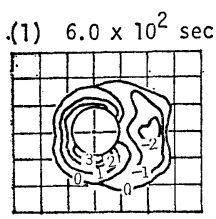

(2) $1.8 \times 10^{3} \mathrm{sec}$

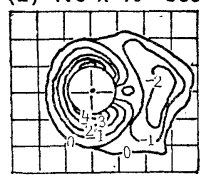

(3) $3.6 \times 10^{3} \mathrm{sec}$

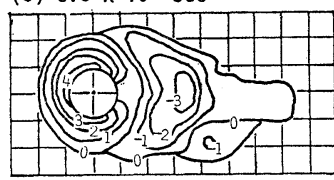

(4) $1.08 \times 10^{4} \mathrm{sec}$

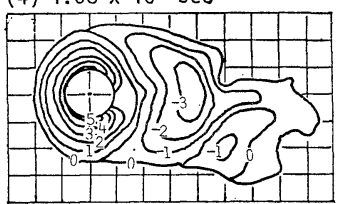

(5) $4.86 \times 10^{4} \mathrm{sec}$

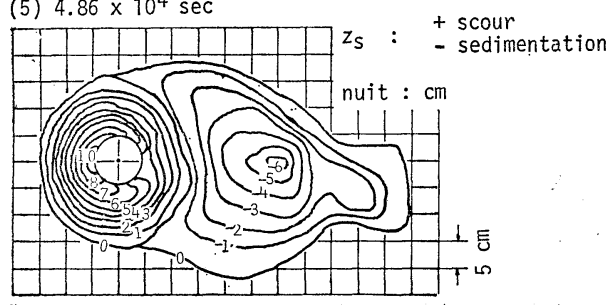

図一2 洗掘孔形状の時間的変化 
頂点とするような逆円錐形から形が若干変化するととも に，逆円錐形の頂点が円柱の上流端へ移ったような形に なっている. 水理条件が静的洗掘の条件であるため, 洗 掘された土砂は遠く一流されることなく, 橋脚の後流部 へ堆積している，橋脚側面から下流側では，側面から円 柱の直径程度下流領域は洗掘領域となっており, それよ り下流側の後流域は洗掘された砂の堆積域となってい る.

\section{（3）最大洗掘深の時間的変化}

図一3 は Run 6 について, 円柱上流端面 (図中 A 点: $\theta=0$ ), 斜め上流面 ( $\mathrm{B}$ 点: $\left.\theta=45^{\circ}\right)$ および側面 ( $\mathrm{C}$ 点: $\left.\theta=90^{\circ}\right)$ における洗掘孔底部の洗掘深の時間的変化 を示しだものである. 洗掘初期には, 円柱の側面 (C 点）から斜め上流面（B点）にかけて洗掘が比較的速く 進行し, 円柱上流端 ( $\mathrm{A}$ 点) での洗掘進行は比較的緩慢 である、しかし，ある程度洗掘が進行すると， B, C 点 付近の洗掘進行が緩慢になるにもかかわらず，A点では 同じような速度で洗掘が進行するため, 本例では, 通水 後約 1 時間で, $\mathrm{A}, \mathrm{B}$ および $\mathrm{C}$ 点での洗掘がほとんどー 致し, それ以降では, 最大洗掘深は $\mathrm{A}$ 点に移っている.

観察によれば, これらの現象は次のような理由から生じ ている. すなわち, 円柱側面では洗掘が進行してゆき河 床が低下すると水深が大きくなり流速の減少に伴って掃 流力が小さくなることと, 円柱側面 $\mathrm{C}$ 点から円柱径程度 下流側以降が洗掘砂の堆積域となっているため, C 点か らこの堆積域にかけての区間が逆勾配となっているが, 洗掘進行とともにこの逆勾配が大きくなり，側面での砂 が動きにくくなる. 一方, 水平軸をもつ渦流のみによっ て洗掘が進行している円柱上流端 $\mathrm{A}$ 点では, 洗掘が進行 しても渦流の強さはほとんど変わらず砂を巻き上げ続け るためである.しかし, 最終的には, この側面で生じた 逆勾配の領域が洗掘進行とともに次第に $\mathrm{A}$ 点近くに移行

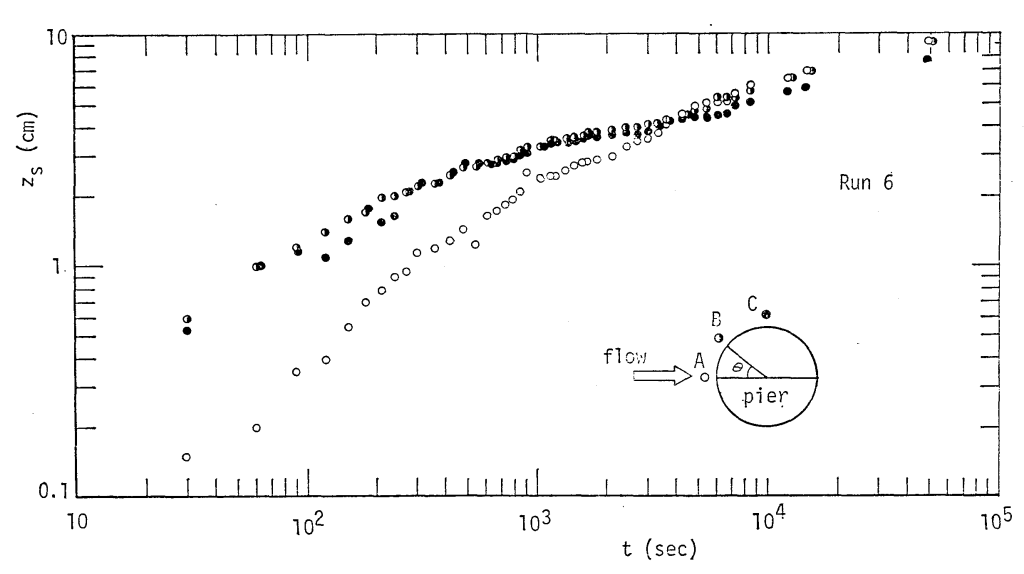

図一3 円柱上流端 (点 A), 斜め上流側 (点 B) および円柱側面 (点 C) における洗掘深の時間的変化
してゅき，A点での洗掘進行も緩慢になっていく.

以上, ここに示した洗掘特性は, 円柱周辺の静的洗掘 進行過程の基本的特徵であって, 水理量によっては少な からず異なっているものもある，それらの詳細は 4.の 図一8 (a) から（g) までに示されている.

\section{3. モデルによる解析}

円柱橋脚周辺の局所洗掘（静的洗掘の場合）の前節で 示された場所的・時間的変化特性を理論的に解析するこ とが本節の目的であるが, 橋脚周辺の局所洗掘現象は 3 次元流によって惹起される現象であり,この流れ特性自 体にもまだ不明な点も多く，それに応答する局所河床形 状を純粋に理論解析することは現段階では困難である. そこで，ここでは前節あるいは従来の研究で明らかにさ れている実験事実に基づくいくつかの仮定のもとにモデ ル解析を試みる.

\section{（1）基 礎 式}

図一4 は円柱橋脚周辺の局所洗掘孔を模式的に示した ものであって, $r_{i}$ は円柱の半径, $r_{v}$ は渦流等によって 実際に洗掘されている領域外縁までの円柱中心からの距 離, $r_{o}$ は橋脚中心から洗掘孔外縁までの距離である. $\left(r_{v}-r_{i}\right)$ の領域（以下，掃流領域とよぶ）の砂が局所流 によって移動しこの掃流領域の河床が低下寸ると， $\left(r_{o}\right.$ $-r_{v}$ ) の領域（洗掘孔斜面）の砂が斜面勾配を砂の水中 静止摩擦角 $\varphi$ に保つように洗掘孔底部の掃流領域一滑 落することによって洗掘が進行していく. いま, 元河床 面から鉛直下向きに洗掘深 $z_{s}$ をとり, 橋脚中心からの 半径方向の距離を $r$, 橋脚中心軸右回りの一様流向から の偏角を $\theta$ として, 図一4 の斜線で示す掃流領域での 土砂の連続式を考える.

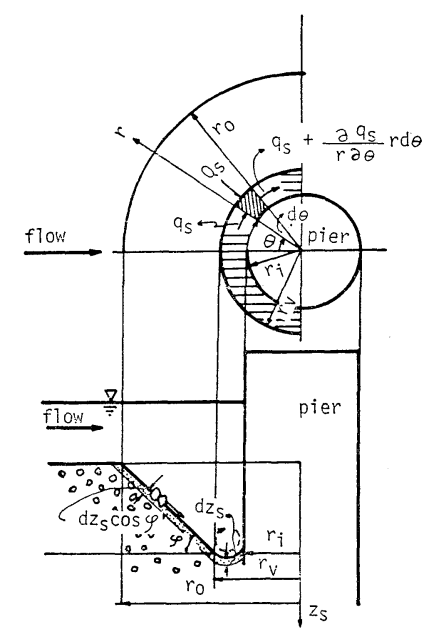

図-4 洗掘孔の模式記号図 
掃流域の河床が $d t$ 時間に $d z_{s}$ だけ低下したときに は, 洗掘孔斜面の傾きが $\varphi$ で保たれるためには斜面河 床も $d z_{s}$ だけ低下し，その低下量に対応する砂が掃流 領域に滑落している. その滑落した砂の単位時間当たり の量を $Q_{s}, \lambda$ を砂の空隚率とすると, 図一4 において 幾何学的関係より,

$$
Q_{s} d t=\frac{1-\lambda}{\cos \varphi}\left(r_{o}^{2}-r_{v}{ }^{2}\right) \frac{d \theta}{2}\left(d z_{s} \cos \varphi\right) \cdots
$$

である.また， $q_{s}$ を掃流領域での円周に沿う方向の単 位幅流砂量とすると, 図一4の斜線部に㧍ける $d t$ 時間 の流砂の連続の関係は,

$$
\begin{aligned}
& \frac{1}{1-\lambda}\left\{\int_{r_{i}}^{r_{v}}\left(q_{s}+\frac{\partial q_{s}}{r \partial \theta} r d \theta-q_{s}\right) d r-Q_{s}\right\} d t \\
& =\left(r_{v}{ }^{2}-r_{i}{ }^{2}\right) \frac{d \theta}{2} d z_{s}
\end{aligned}
$$

で表わされるから，この式に式 (1) を代入し， $q_{s}$ の $r_{i}$ $<r<r_{v}$ での平均を $\bar{q}_{s}$ とすると（以後 - は $r_{i}<r$ $<r_{v}$ での平均を示す),

$$
\frac{1}{2}\left(r_{0}^{2}-r_{i}^{2}\right) \frac{\partial z_{s}}{\partial t}-\frac{1}{1-\lambda}\left(r_{v}-r_{i}\right) \frac{\partial \bar{q}_{s}}{\partial \theta}=0
$$

で示される河床変動に関する基礎式が得られる. 局所的 な河床変動が生じていないときの馬蹄型渦流の半径方向 の規模は水理量によらずほぼ円柱径 $D$ のみによって決 まり, $k_{1} D / 2\left(k_{1}:\right.$ 定数 00.5$)$ で示されるが ${ }^{10}$, 馬蹄型 渦流の存在領域と洗掘領域 $\left(r_{v}-r_{i}\right)$ にほぼ対応すると 考えられるから， $r_{v} \simeq\left(1+k_{1}\right) D / 2$ と仮定することがで きよう.また，実験によって観察されるように渦流の規 模が洗掘進行後もほぼ不変であると仮定すると, 式 (2) の $r_{i}, r_{v}$ および $r_{o}$ は，次式 (3) で示される.

$$
\left.\begin{array}{l}
r_{i}=D / 2 \\
r_{v}=\left(1+k_{1}\right) D / 2 \\
r_{o}=r_{v}+\left(z_{s} / \tan \varphi\right)=\left(1+k_{1}\right) D / 2+z_{s} / \tan \varphi
\end{array}\right\}
$$

$r_{i}, r_{v}$ は時間 $t$ あるいは場所 $\bar{r} \theta\left(\bar{r}=\left(r_{v}+r_{i}\right) / 2\right)$ によ って変化しないが， $r_{o}$ は $z_{s}$ の関数であるから $t$ およ び $\bar{r} \theta$ の関数である.

次に, 式 (2) の洗掘領域における $r$ 方向に平均した 単位幅流砂量 $\bar{q}_{s}$ についてであるが, 局所洗掘状態にお いては，場所的 $(\bar{r} \theta)$ にも掃流力が異なることと，平衡 一様流状態のように無限に上流からの土砂供給がないた め, $\bar{q}_{s}$ は非平衡状態の流砂量であって, その場所の水 理条件だけでは決まらず 上流の条件によって決定 される. 非平衡状態の流 砂量に関する考察が, Tsuchiya $^{11)}$ や斉藤 ${ }^{12)}$ に よって水門下流部におけ

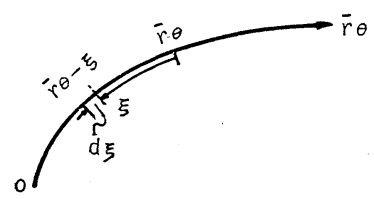

図-5 記 号 図
る水平噴流による局所洗掘現象の解明の際に初めてなさ れたが，同様な考え方をここに適用すると，式 (2) にお ける $(1 / \bar{r}) \partial \bar{q}_{s} / \partial \theta$ は，図一5 に示す記号を用いて，

$$
\frac{\partial \bar{q}_{s}}{\bar{r} \partial \theta}=A d\left\{p_{s}(\bar{r} \theta)-\int_{0}^{\bar{r} \theta} p_{s}(\bar{r} \theta-\xi) f(\xi) d \xi\right\}
$$

で示される.ここに, $p_{s}(\bar{r} \theta)$ および $p_{s}(\bar{r} \theta-\xi)$ はそれ ぞれ，移動床が始まる原点からの流下方向距離 $\bar{r} \theta$ およ び $\bar{r} \theta-\xi$ 地点における単位時間当たりの河床砂の移動 確率, $f(\xi)$ 砂の跳躍距離の確率密度関数であって, 実験によると $L$ を砂の平均跳躍距離として, $f(\xi)=$ $(1 / L) \exp (-\xi / L)$ で示される ${ }^{13)} . d$ 注砂粒径, $A$ 沙砂 の形状に特有な定数である.また， $L$ は Einstein ${ }^{14)}$ に よると $L=\lambda_{1} d\left(\lambda_{1} \approx 100\right)$ であって砂粒径のみによって 決まる.

いま, $\bar{r} \theta$ 地点の掃流力に対応する平衡状態の流砂量 を $\bar{q}_{s o}(\bar{r} \theta)$ とすると, $\bar{q}_{s 0}(\bar{r} \theta)=p_{s}(\bar{r} \theta) A \cdot d \cdot L$ と表わ されるから，これらの関係と式 (3) および式 (4) を式 (2) に代入して, 整理無次元化を行うと次式 (5) が得ら れる.

$$
\begin{aligned}
\frac{\partial z_{s}^{*}}{\partial t^{*}}= & \frac{K^{*}}{G^{*}\left(z_{s}^{*}\right)}\left\{\bar{q}_{s o^{*}}\left(\bar{r}^{*} \theta, t^{*}\right)\right. \\
& \left.-\int_{0}^{\bar{r}^{*} \theta} \bar{q}_{s o} *\left(\bar{r}^{*} \theta-\xi^{*}, t^{*}\right) \frac{1}{L^{*}} \exp \left(-\frac{\xi^{*}}{L^{*}}\right) d \xi^{*}\right\}
\end{aligned}
$$

ただし，

$$
\begin{gathered}
K^{*}=\frac{\left(2+k_{1}\right) k_{1}}{4 L^{*}(1-\lambda)} \\
G^{*}\left(z_{s}^{*}\right)=\frac{k_{1}}{2}\left(1+\frac{k_{1}}{2}\right)+\left(1+k_{1}\right) \frac{z_{s}^{*}}{\tan \varphi}+\left(\frac{z_{s}^{*}}{\tan \varphi}\right)^{2} \\
z_{s}^{*}=\frac{z_{s}}{D}, t^{*}=\frac{v_{o} t}{D}, L^{*}=\lambda_{1} \frac{d}{D}, \bar{q}_{s o}=\frac{\bar{q}_{s o}}{v_{o} D} \\
\bar{r}^{*}=\frac{\bar{r}}{D}, \quad \xi^{*}=\frac{\xi}{D}
\end{gathered}
$$

である. 式 (5) は局所洗掘深 $z_{s}$ の場所 $(\bar{r} \theta)$ 的, 時間 $(t)$ 的変化を示す方程式であって, 各地点に扔ける掃流 力に対応する平衡状態の流砂量 $\bar{q}_{s o}$ が時間的に求まれ ぼ，計算によって $z_{s}$ の場所的・時間的変化を決定する ことができる。

\section{（2）平衡状態の流砂量}

式（5）に拈ける平衡状態の流砂量 $\bar{q}_{s o}$ を求めるに際 し，他の仮定の精度との整合性から考えるといたずらに 複雑な流砂量式を用いてもあまり意味がないので，こ こでは従来提案されている式の中で比較的形の単純な Meyer-Peter \& Müller 型の流砂量式,

$$
\frac{\bar{q}_{s o}}{\sqrt{s g d^{3}}}=C\left(\bar{\tau}_{*}-\bar{\tau}_{* c}\right)^{m}
$$

を修正して用いることにする．ここに， $\bar{\tau}_{*}=\bar{u}_{*}{ }^{2} / s g d$ ， 
$\bar{\tau}_{* c}=\bar{u}_{* c}{ }^{2} / s g d, \bar{u}_{*}$ および $\bar{u}_{* c}$ (一 は掃流領域の半径方 向平均を示す）はそれぞれ摩擦速度㧍よび砂の限界摩擦 速度， $s=\sigma / \rho-1 ， \sigma$ 拉よび $\rho$ はそれぞれ砂打よび水の 密度, $g$ は重力加速度である.

さて，式（6）を用いて $\bar{q}_{s o}$ を計算するためには摩擦 速度 $\bar{u}_{*}$ の大きさを知らなければならない. 洗掘孔底部 (掃流領域) での $\bar{u}_{*}$ は円柱周に沿っても時間的にも変 化するためにその大きさを正確に求めることは困難であ るが，上に述べた実験的事 実を踏まえたいくつかの仮 定のもとに $\bar{u}_{*}$ の評価を試 みる. 洗掘が進行する以前 の掃流領域作用する河床 面せん断力 $\bar{\tau}$ を図一6 に みられるよらに, 洞流によ る円柱の半径方向のせん断 力 $\bar{\tau}_{r}$ と円周方向の流れに よる円周に沿う方向のせん

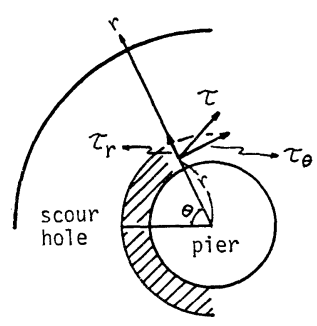

图一6 掃流領域のせん断力 の記号図
断力 $\bar{\tau}_{\theta}$ とに分けて考える. いま, 仮に洗掘前の $\bar{r} \theta$ に おける円周方向の流速 $\bar{v}_{\theta}$ (水深方向にも平均した流速) が $r \simeq D / 2$ の点でのポテンシャル流で近似され,

$\bar{v}_{\theta} \simeq 2 v_{o} \sin \theta\left(v_{o}:\right.$ 一様流の平均流速)

で示されるとし, 洗掘進行後洗掘深が $z_{s}$ になったとき には，

$$
\bar{v}_{\theta} \simeq 2 v_{o} \sin \theta \frac{h_{o}}{h_{o}+z_{s}}\left(h_{0}: \text { 一様流の水深 }\right)
$$

で示されるものと考える. $\varphi_{\theta}$ をそこでの流速係数とす ると, $\tau_{\theta}$ は,

$$
\bar{\tau}_{\theta}\left(\equiv \rho u_{* \theta}{ }^{2}\right)=\rho \varphi_{\theta}^{-2} \bar{v}_{\theta}^{2} \simeq 4 \rho \varphi_{\theta}{ }^{-2} \sin ^{2} \theta\left(\frac{h_{0}}{h_{o}+z_{s}}\right)^{2} v_{o}^{2}
$$

となる・

一方, 洗掘前 (固定床) の $\bar{\tau}_{r}$ については, $\bar{\tau}_{r}$ も $\bar{\tau}_{\theta}$ と同様にほぼ $\rho v_{o}^{2}$ に比例する(0)ことがわかっているか ら，その比例定数を $\varphi_{r}^{-2}$ とすると，

$$
\bar{\tau}_{r} \simeq \rho \varphi_{r}{ }^{-2} v_{o}{ }^{2}
$$

と表わせるが, 前にも述べたように, 渦流の規模および 強さが洗掘進行後も, 場所的にもほぼ変わらないことが 実験的に観察されていることから， $\bar{\tau}_{r}$ は $\bar{\tau}_{\theta}$ と違って 巨視的には場所的にも時間的にも変わらないと仮定でき よう. 吉川ら によると, 一様流での 河床面 せん断力 $\tau_{0}$ と橋脚上流端部における渦流による河床でのせん断 力 $\tau_{r}$ との比は実験的には $\bar{\tau}_{r} / \tau_{o} \approx 1.5$ ということが示 されている.したがって，いまこの結果を用いるとする と, 式 (8) から $\rho \varphi_{r}{ }^{-2} v_{o}^{2} / \rho u_{* o}{ }^{2} \simeq 1.5\left(u_{* o}\right.$ : 一様流部で の摩擦速度）であるから，

$$
\varphi_{r} \simeq 0.82 \varphi_{o}, \varphi_{o} \equiv v_{o} / u_{* o}
$$

となるが, $\varphi_{0}$ については, 静的洗掘では一様流での河
床は平坦であるので, $\varphi_{o}=6.0+5.75 \log \left(h_{o} / d\right)$ で与え

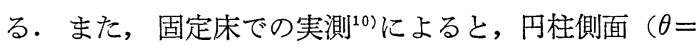
$\pi / 2)$ の円柱近傍河床では $\bar{\tau} / \tau_{o} \simeq 4$ であるから, 式 (7) 〜 (9) および $\bar{\tau}=\sqrt{\tau_{r}^{2}+\tau_{\theta}^{2}}$ の関係を用いると,

$$
\varphi_{\theta} \simeq 1.04 \varphi_{0}
$$

となる. 式 (9) と（10）の関係が洗掘進行後も成り立つ ものと仮定すると，洗掘深が $z_{s}$ のときの摩擦速度 $\bar{u}_{*}$ は, $\rho \bar{u}_{*}{ }^{2}=\sqrt{\overline{\bar{\tau}}_{r}{ }^{2}+\bar{\tau}_{\theta}{ }^{2}}$ であるから, 式 (7) (9) を用い $\tau$,

$$
\bar{u}_{*}=\left\{2.2+13.7 \sin ^{4} \theta\left(\frac{h_{o}}{h_{o}+z_{s}}\right)^{4}\right\}^{1 / 4} \frac{v_{o}}{\varphi_{o}}
$$

となる.すなわち, 洗掘領域で $\bar{r} \theta$ での平均的摩擦速度 は, 一様流での平均流速 $v_{o}$, 水深 $h_{o}$ および流速係数 $\varphi_{0}$ とその場所での局所洗掘深 $z_{s}$ および $\theta$ の関数で表 わされる. 河床面せん断力 $\bar{\tau}\left(\equiv \rho \bar{u}_{*}^{2}\right)$ の方向と円周に 沿う方向とのなす角を $\alpha_{1}$ とすると, $\tan \alpha_{1}=\bar{\tau}_{r} / \bar{\tau}_{\theta}$ で

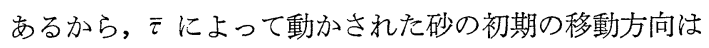
必ずしも円周に沿う方向ではないが, 砂が河床から浮き 上がると渦流に巻き込まれるようにして円周に沿う掃流 領域を移動していく. したがって, 半径方向に動かされ た砂も掃流領域系全体からみると円周方向に $\bar{\tau}$ にっ て動かされていると考えてもよいであろう。

次に式 (6) における無次元限界掃流力であるが, 洗掘 孔底部の掃流領域内でも円周に沿う方向に洗掘深が異な るため, 河床が傾きを有しており砂の移動のしやすさが 異なり $\tau_{* c}$ も場所的に変化していると考えられる. 図 -7のように, 傾き $\alpha$ の河床上での砂の移動限界状態で は， $C_{D}, C_{L}$ をそれぞれ抗力係数および揚力係数とし, $k_{1}, k_{2}$ および $k_{3}$ を砂粒子の形状に関する係数, $\left(u_{b}\right)_{c r}$ を河床における限界流速とすると,

$$
\frac{\left(u_{b}\right) c r^{2}}{s g d}=\frac{2 k_{3}(\tan \varphi \cos \alpha-\sin \alpha)}{C_{D} k_{1}+C_{L} k_{2} \tan \varphi}
$$

である ${ }^{15)}$ から, 水平河床での無次元掃流力 $\tau_{* c}(o)$ と河 床勾配が $\propto$ でのそれ $\tau_{* c}(\alpha)$ の関係は,

$$
\frac{\tau_{* c}(\alpha)}{\tau_{* c}(o)}=\cos \alpha-\frac{\sin \alpha}{\tan \varphi}
$$

となる.したがって, 式 (6) における $\bar{\tau}_{* c}$ としては式 (13) で表わされる $\tau_{* c}(\alpha)$ を用いなければならない.

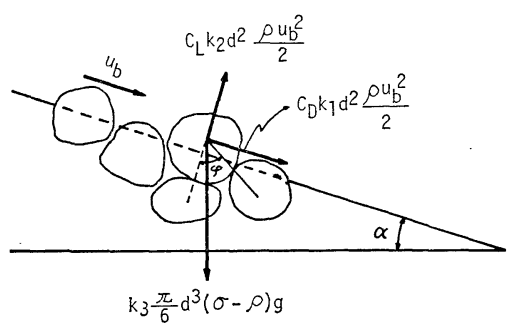

図一7 斜面上の砂礫に作用する力 


\section{4. 解析結果と実験結果との比較}

\section{(1) 数 值計算}

式 (11) を式 (6) に代入することによって，洗掘深が $z_{s}$ のときの掃流領域における任意断面 $(\bar{r} \theta)$ での掃流 力に対応する平衡流砂量 $\bar{q}_{s o}$ を計算し，これを基礎式 （5）に代入したのち，差分化して数值計算によって $z_{s}$ の場所的・時間的変化を求める. 計算域 は 円柱上流端 $(\theta=0)$ から掃流領域に沿って円柱側面 $(\theta=\pi / 2)$ まで で，この区間を 11 区間に分割して $\Delta \bar{r} \theta$ を与え，計算 時間間隔 $\Delta t$ は $t=10$ 秒までは 2 秒, $t=10 \sim 500$ 秒では 4 秒， 500 秒以降は 25 秒とした. 初期条件としては, $t=0$ で $z_{s}=0$ とし， $\tau_{* c}(\alpha)$ を与えるために必要な河 床勾配 は, 前後の断面の河床高との関係で与えられる が，円柱側面（第 12 断面）での河床勾配は, 実験のと ころで述べたように，円柱側面から円柱径 $D$ 程度下流 側までは洗掘域であってなだらかに河床が上がっている とし，その勾配 $\alpha_{12}$ は $\alpha_{12}=-\tan ^{-1}\left(z_{s}(12) / D\right)$ （逆勾 配）で与えた。ただし， $z_{s}(12)$ は円柱側面における洗 掘梁である. $\tau_{* c}(o)$ としては一般には，0.03 0.06 で あるが, 洗掘孔内では結果的にこれは大き過ぎ 0.015 と かなり小さくとった．また，流砂量式 (6) の係数 $C$ お よび $m$ については， $C=20, m=1$ として計算した. こ れらの值は，全実験ケースについて洗掘進行が実測と計 算とで比較的よく一致するように試行錯誤的に求めたも のであり， $\tau_{* c}(o), C$ および $m$ の上記の值で与えられ る流砂量は掃流力が限界掃流力に近いところで，従来の 流砂量式で与えられるものよりかなり大きいが，掃流力 が大きいときは逆となっている．洗掘孔内では，流れの 変動が比較的大きいため, 砂が移動しやすい状態にある ため $\tau_{* c}(o)$ が小さくなっていると考えられよう.

\section{（2）計算結果と実測との比較}

図一8 (a)〜 (g) は， $z_{s} / D$ と $v_{0} t / D$ との関係を表わし たものであって，図中丸印が実測值で，曲線が計算結果 を示している.（a）図中に示しているように，○印と 点線が円柱上流端部 ( $\theta=0, \mathrm{~A}$ 点), 印と破線が斜め 上流側 $\left(\theta=45^{\circ}, \mathrm{B}\right.$ 点), 印と実線 $90^{\circ}, \mathrm{C}$ 点) での洗掘進行状態を示している. 各 Run の 実験条件は 表一2 に示されている. Run 1 についてみ ると, 洗掘初期では $\mathrm{C}$ 点が最も洗掘が進んでおり $\mathrm{A}$ 点は 遅れていて，B点はその間にあるが， $v_{0} t / D \simeq 7 \times 10^{2}$ 程 度で $\mathrm{A}$ 点と $\mathrm{B}$ 点での洗掘媣が一致し， $v_{0} t / D \simeq 4 \times 10^{3}$ 程 度で $\mathrm{A}, \mathrm{B}, \mathrm{C}$ 点でほとんど等しくなり以後わずかであ るが， $\mathrm{C}$ 点での洗掘深が $\mathrm{A}$ 点， $\mathrm{B}$ 点に比して小さくなっ
ている.これらの特性は，実測と計算とで非常によく一 致している. Run 1 と同じ径の円柱 $(D=14 \mathrm{~cm})$ と同 じ砂 $\left(d_{50}=0.193 \mathrm{~cm}\right)$ で流速を大きくした場合の Run 2 では， $\mathrm{A}, \mathrm{B}$ および $\mathrm{C}$ 点とも洗掘初期から大きく洗掘 されており，乙かも各点間での差は小さい。これらの傾 向は実測と計算とでほぼ一致はしているが，全体的な傾

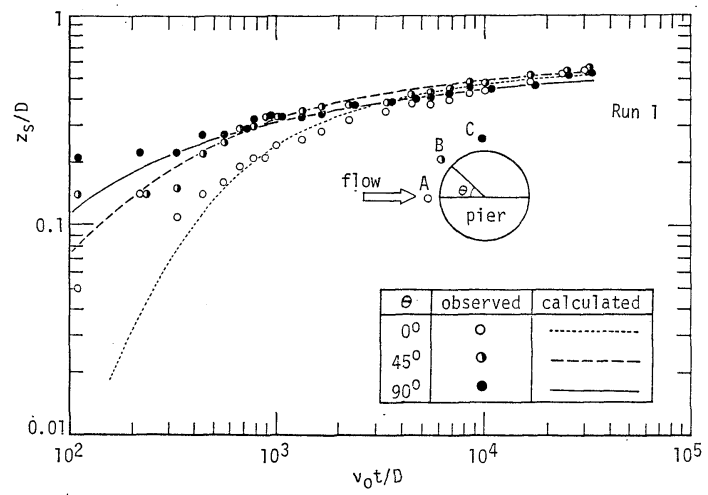

(a) $D=14.0 \mathrm{~cm}, d_{50}=0.193 \mathrm{~cm}, v_{0}=26.05 \mathrm{~cm} / \mathrm{s}$

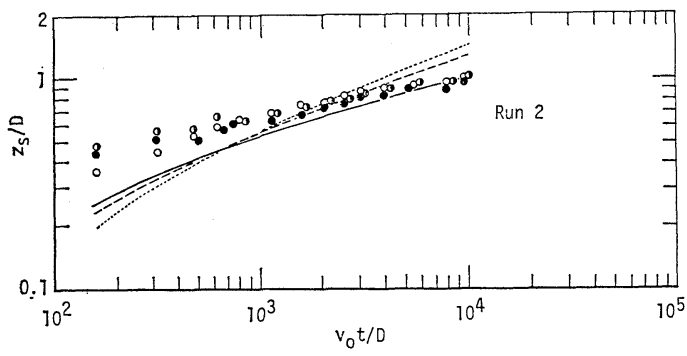

(b) $D=14.0 \mathrm{~cm}, d_{50}=0.193 \mathrm{~cm}, v_{o}=37.04 \mathrm{~cm} / \mathrm{s}$

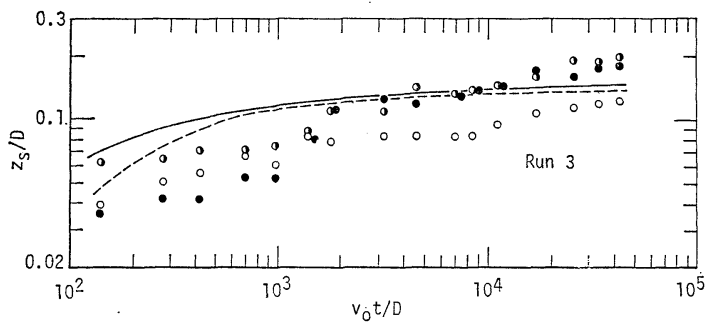

(c) $D=8.9 \mathrm{~cm}, d_{50}=0.193 \mathrm{~cm}, v_{0}=20.80 \mathrm{~cm} / \mathrm{s}$

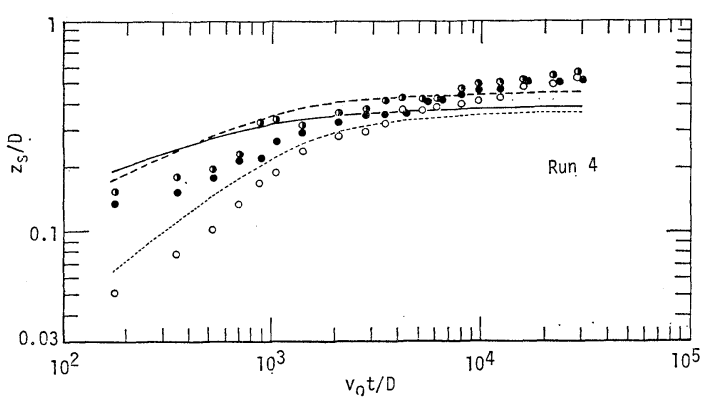

(d) $D=8.9 \mathrm{~cm}, d_{50}=0.193 \mathrm{~cm}, v_{o}=26.05 \mathrm{~cm} / \mathrm{s}$ 


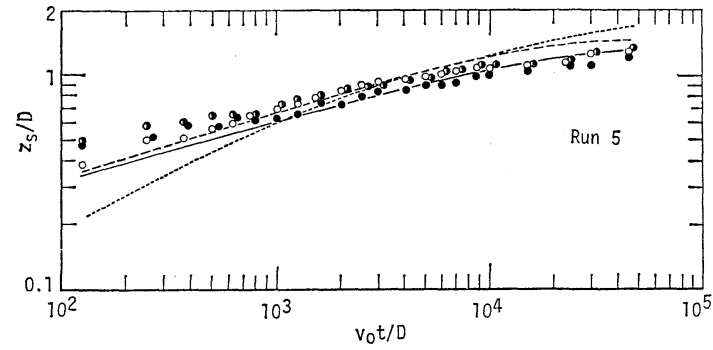

(e) $D=8.9 \mathrm{~cm}, d_{50}=0.193 \mathrm{~cm}, v_{o}=37.04 \mathrm{~cm} / \mathrm{s}$

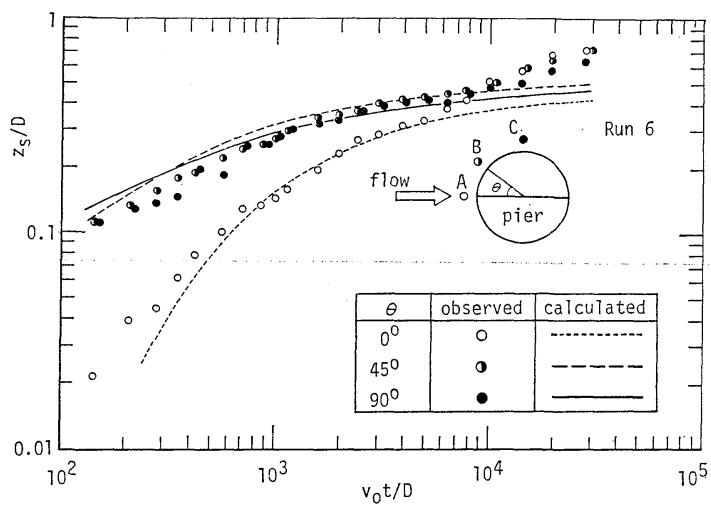

(f) $D=8.9 \mathrm{~cm}, d_{50}=0.083 \mathrm{~cm}, v_{o}=20.80 \mathrm{~cm} / \mathrm{s}$

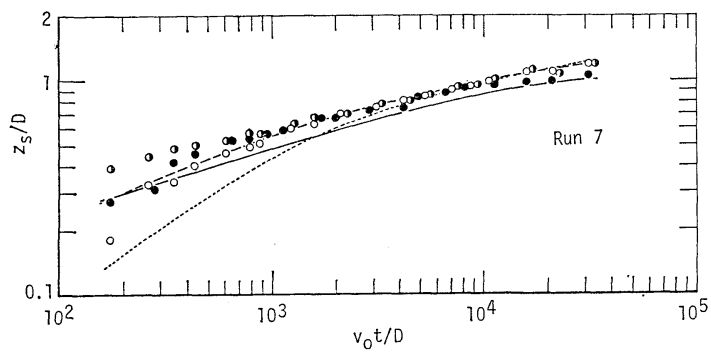

（g） $D=8.9 \mathrm{~cm}, d_{50}=0.083 \mathrm{~cm}, v_{o}=26.05 \mathrm{~cm} / \mathrm{s}$

\section{図一8 A, B および C 点における洗掘深の時間的変化}

向としては, 実測の方の洗掘深が洗掘初期に大きくなっ ており，あまりよくシミニレートされていない. Run 3 から Run 7 までは円柱径が $8.9 \mathrm{~cm}$ であって，まず Run 3 は砂粒径が $0.193 \mathrm{~cm}$ と大きく, 流速が小さい 場合で, 洗掘はほとんど生じない.計算ではA点では洗 掘深が 0 であって（c）図中 ○印に対応する曲線がない が，実測も最終的に $z_{s} / D \simeq 0.1$ と小さいけれども洗掘 は生じている. B 点, C点については比較的計算と実測 は一致している. Run 4 および Run 5 は Run 3 の条 件で流速のみを大きくしたものであり， A, B, C 各点で の洗掘進行特性は実測と計算とでほぼ一致している。ま た, Run 6 と Run 7 は砂粒径が $0.083 \mathrm{~cm}$ と小さい 場合について検討したものである. Run 6 では， $v_{0} t / D$ 〜10 ${ }^{4}$ 程度まで実測と計算による洗掘進行特性は非常に よく一致しているが，それ以降実測の洗掘深がかなり大
きくなっている. Run 7 では洗掘のごく初期を除いて， 計算曲線は実測 データをほぼ説明していることがわか る.

以上，細かくみると実測結果と計算結果とは十分一致 しないところはあるものの，全体的には，種々の水理条 件に対しても両者はほぼ一致しており，モデル解析の大 筋の妥当性は示されているものと考える.

\section{5.あとがき}

本研究は, 円柱橋脚周辺部における静的洗掘の場所 的・時間的変化特性について, 詳細な実験を行らととも に理論的な検討を加えたが，得られたおもな結果は以下 のとおりである.

（1）洗掘孔内で実際に砂が流れによって掃流されて いる領域は円柱にごく近い一部河床で，他の部分はその 掃流領域の河床低下に伴って形成される砂の水中静止摩 擦角をその勾配とする斜面である.

（2）局所洗掘を起こす流れは, 橋脚周辺底部に発生 する馬蹄型渦流と橋脚側面近くで卓越する縮流であるた め, 洗掘初期には, 縮流と渦流の両方が存在する円柱斜 め前面から側面にかけての洗掘が円柱上流端より大きい が, 洗掘深が大きくなり通水断面が大きくなると, 縮流 流速が小さくなり, 円周に沿ってほとんど強さが変わら ない渦流のみによって洗掘が進行するようになるため， 上流側からの流入砂の少ない円柱上流端部の洗掘深が相 対的に大きくなっていく.

（3）洗掘孔内における非平衡状態の流砂量をも考慮 した 流砂の連続式（5）を導き，いくつかの仮定のもと に, 洗掘孔掃流領域での摩擦速度を与え数值計算により 式 (5) を解くことによって, 洗掘深の場所的・時間的変 化を解析的に求めることを可能にした.

（4）解析結果と実測值を比較した結果, 微視的には 両者は一致しないところはあるものの大筋において理論 による洗掘深の場所的・時間的変化特性は実測のものと 一致しており, 本モデル解析の妥当性が示された.

本研究を行うにあたり，懇切なご指導をいただいた京 都大学工学部 中川博次教授および鳥取大学工学部 道 上正䂓教授に深く感謝の意を表わす。

\section{参 考 文 献}

1) Laursen, E.M. : An Analysis of Relief Bridge Scour, Proc. of ASCE, Vol. 89, HY 3, pp. 93 118, 1963.

2) 斉藤 隆・浦 勝・柴田幸信 : 円柱周囲の洗掘について, 山口大学工学部研究報告, 第 20 巻, 第1 号, pp. 83 90, 1969.

3) Gradowozyk, M.H., O.J. Maggiolo and H.C. Folguera : Localized Scour in Erodible-Bed Channels, 
Jour. of Hydraulic Research, Vol. 6, No. 4, pp. 289 〜326, 1968.

4) Carstens, M.R. : Similarity Laws for Localized Scour, Proc. of ASCE, Vol. 92, HY 3, pp. 13 36, 1966.

5) Shen, H.W., V.R. Schneider and S. Karaki : Local Scour around Bridge Piers, Proc. of ASCE, Vol. 95, HY 6, pp. 1914 1938, 1969.

6) Tanaka, S. and M. Yano : Local Scour around a Circular Cylinder, Proc. of 12th Congress of IAHR, Vol. 3, pp. 193 201, 1967.

7）吉川秀夫・福岡捷二・岩間 汎・曾小川久貴 : 橋脚の洗 掘ならびにその防止に関する考察, 土木学会論文報告集, 第 194 号, pp. 83〜90, 1971.

8) Tarapore, Z.S. : A Theoretical and Experimental Determination of the Erosion Pattern Caused by Obstruction in an Alluvial Channel with Particular Reference to Vertical Circular Cylindrical Piers, Ph. D. Thesis, University of Minnesota, 1962.

9）中川博次・鈴木幸一：橋脚による局所洗掘深の予測に関
する研究, 京都大学防災研究所年報, 第 17 号 B, pp. 725 〜51, 1974.

10）鈴木幸一：橋脚周辺部における流れと掃流力に関する研 究, 土木学会論文報告集, 第 272 号, pp. 65 78, 1978.

11) Tsuchiya, Y.: On the Mechanism of the Local Scour from Flows Downstream of an Outlet, Proc. 12th Congress of IAHR, Vol. 3, 1967.

12）斉藤 隆: 水平噴流による洗掘に関する研究, 土木学会 論文報告集，第 282 号, pp. 53 63, 1979.

13）矢野勝正・土屋義人・道上正䂓：砂䃯の流送機構の確率 過程としての特性について, 京都大学防災研究所年報, 第 11 号 B, pp. 61 73, 1968.

14) Einstein, H.A. : The Bed Load Function for Sediment Transportation in Open Channel Flows, U.S. Dept. Arg. Tech., Bull. 1026, 1950.

15) Graf, W.H. : Hydraulics of Sediment Transport, McGraw-Hill, p. 85, 1971. 